\title{
O imbróglio de Raízes: notas sobre a fortuna crítica da obra de Sérgio Buarque de Holanda ${ }^{1}$
}

\author{
The imbroglio of Raízes: notes on the criticism's \\ fortune of the work of Sérgio Buarque de Holanda
}

Ronaldo Vainfas*

\section{Resumo}

$\mathrm{O}$ artigo analisa as condições de produção e recepção da obra inaugural de Sérgio Buarque de Holanda, Raízes do Brasil, considerando a crítica historiográfica sobre o autor. Nesse sentido, comenta a controvérsia sobre as edições de Raízes; analisa a "teoria da América" que inspirou o livro de 1936; reflete sobre a presença da filosofia e da historiografia alemã, bem como da francesa, na produção de Sérgio. Por fim, à guisa de conclusão, analisa a polêmica em torno do pensamento político de Sérgio ao longo do século XX.

Palavras-chave: Sérgio Buarque de Holanda; Teoria da América; Raízes do Brasil; Historiografia brasileira.

\begin{abstract}
The article analyzes the conditions of production and reception of the inaugural work of Sérgio Buarque de Holanda, Raízes do Brasil, taking into account the historiographic criticism about the author. In this sense, it addresses the controversy over the book's editions; analyzes the "theory of America" of its inspiration; and reflects on the presence of German and French philosophy and historiography in the production of Sérgio. Finally, it analyzes the polemic on Sergio's political thinking throughout the twentieth century.

Keywords: Sérgio Buarque de Holanda; Theory of America; Raízes do Brasil; Brazilian historiography.
\end{abstract}

\section{PERCALÇOS DA OBRA}

Oitenta anos de Raízes do Brasil, obra inaugural de Sérgio Buarque de Holanda, sem dúvida o mais completo, o mais erudito historiador brasileiro. Nem tanto por esse livro inaugural, senão pela vasta obra que produziu nas décadas seguintes, especialmente entre os anos 1940 e 1960. Raízes do Brasil

\footnotetext{
* Faculdade de Formação de Professores (FFP)/Universidade Estadual do Rio de Janeiro (Uerj), professor visitante; Universidade Federal Fluminense (UFF), Centro de Estudos Gerais. Niterói, RJ, Brasil.rvainfas@terra.com.br ${ }^{2}$
} 
permaneceu, porém, como a grande referência bibliográfica do autor no meio intelectual brasileiro, ofuscando, por décadas, as obras de um Sérgio Buarque amadurecido enquanto historiador. Livros como Monções (1945), Caminhos e fronteiras (1957) e Visão do Paraíso (1959) permaneceram pouco conhecidos e raras vezes citados, inclusive em textos acadêmicos.

Monções só foi republicado em 1976, 30 anos depois da primeira edição. Caminhos e fronteiras, livro premiado pelo Instituto Nacional do Livro em 1957, só ganhou segunda edição em 1975, passados quase 20 anos. Visão do Paraíso saiu em segunda edição em 1969, 10 anos após a edição original. Sérgio não era mais vivo quando esses livros alcançaram ampla repercussão, a partir das décadas de 1980/90. Essa mudança coincidiu com a superação da história econômica de inspiração marxista pela historiografia universitária do país, cada vez mais aberta a temáticas inscritas no campo da história cultural, o predileto de Sérgio Buarque. Como dele se disse certa vez, era compulsivamente levado, por temperamento, a "remar contra a maré", infenso a modismos, uma postura tanto mais assumida quanto ele mesmo refinava o seu trabalho de historiador (In: Meira; Eugenio, 2008, p.119). A obra de conjunto pagou o preço, em termos de repercussão, pela independência intelectual do historiador.

Em certa medida, Raízes do Brasil custou a ser incorporado como obra de referência da nossa historiografia. Durante o Estado Novo, quando o regime criou uma revista que concedeu largo espaço à História do Brasil - a Cultura Política -, Sérgio dela não participou como colaborador, tampouco o Raízes foi incluído entre as obras fundamentais de nossa historiografia, nas seções a elas dedicadas. À diferença de Gilberto Freyre, que não apenas publicou vários artigos, como sua obra autoral, a começar pelo Casa-grande e senzala (1933), encontrou ali seu primeiro pódio (Gomes, 1996, p.188, 195-196). A segunda edição de Raízes apareceu em 1948, 12 anos depois da primeira. A terceira em 1956, passados 8 anos da anterior; a quarta, em 1963, um hiato de 7 anos; a quinta em 1969, o intervalo mais curto até então, incluindo o célebre prefácio de Antonio Candido. É possível dizer que o avanço de Raízes, em termos editoriais, só começou no final dos anos 1960: cinco reedições, entre 1969 e 1979, tempo em que o regime militar brasileiro transitou, nas palavras de Elio Gaspari, da "ditadura escancarada" para a "ditadura derrotada". Não deixa de ser intrigante que o sucesso editorial de Raizes tenha sido alavancado nesse período. Mas foi sucesso tardio, a exemplo do ocorrido com o principal da obra de Sérgio Buarque. Raízes do Brasil, sua obra-prima, teve repercussão muito modesta, se comparado com Casa-grande e senzala, de Freyre, e com Formação do Brasil Contemporâneo, de Caio Prado Júnior - para citar os três livros 
fundamentais de nossa historiografia no século XX, conforme assinalou Candido no prefácio de 1967. Casa-grande foi reeditado cinco vezes entre 1933 e 1946 (13 anos); Formação o foi quatro vezes, entre 1942 e 1953 (11 anos); Raízes apenas duas, entre 1936 e 1948 (12 anos).

A confirmar essa misfortune que atingiu Raízes, basta comparar o seu desempenho editorial com o de dois outros livros de síntese, publicados entre as décadas de 1950 e 1970. Formação Econômica do Brasil, de Celso Furtado, de 1959, alcançaria sua $13^{\text {a }}$ edição em 1977, seis delas nos anos 1970. Formação Histórica do Brasil, de Nelson Werneck Sodré, conheceu nove edições entre 1962 e 1976, três delas nos anos 1970. Os citados livros atravessaram incólumes os "anos de chumbo" da ditadura, prestigiados no meio universitário. Temos, portanto, um paradoxo formidável. Raízes do Brasil só deslanchou de vez a partir da quinta edição, de 1969. Mas, comparada às explicações da história brasileira, apresentadas por autores mais à esquerda, a interpretação do Brasil oferecida em Raízes obteve modesta repercussão, quando não foi deliberadamente distorcida. Talvez porque aqueles tratavam de história econômica (ou sustentavam o determinismo econômico), enquanto Sérgio sempre adotava uma perspectiva sociocultural que fugia, por assim dizer, aos padrões mais valorizados naqueles anos.

O autor "remava contra a maré", mas também Gilberto Freyre remou contra a maré, em seu livro de 1933, ao celebrar a mestiçagem como marca da formação do povo brasileiro. Caio Prado Júnior também remou contra a maré em seu livro de 1942, uma síntese marxista bem fundamentada, histórica e geograficamente, sobre a exploração portuguesa no Brasil, inserindo-a em um sistema colonial mais amplo e complexo. Raízes do Brasil, quando publicado, talvez fosse o que menos desafiava a correnteza, dentre os três autores em foco. Os debates recentes sobre a obra buarquiana têm avançado nessa linha interpretativa. Sem a intenção de esquadrinhá-los, o ponto de partida é, sem dúvida, a opinião de Antonio Candido sobre Raízes e seu autor, esboçada no prefácio de 1967 e adensada em artigos posteriores. No post-scriptum à edição comemorativa do cinquentenário de Raízes, Candido caracterizou Sérgio, politicamente, como "um coerente radical democrático", em razão de ter apostado, desde os anos 1930, na iniciativa do povo para "cuidar do seu destino" (In: Holanda, 1995, p.23). Repetiu a ideia, pouco depois, com outras palavras: "foi o primeiro historiador (brasileiro) que aludiu à necessidade de despertar a iniciativa das massas, manifestando assim um radicalismo democrático, raro naquela altura, fora dos pequenos agrupamentos de esquerda" (Candido, 1998, p.86). 
Sérgio Buarque sempre foi um "democrata radical”, como sugerido por Candido em reiteradas ocasiões? Sempre foi politicamente de esquerda - adepto das iniciativas populares para mudar a história do Brasil -, como se infere do radicalismo que lhe foi atribuído?

Não se pode duvidar de que o Sérgio Buarque dos anos 1940 assumiu, progressivamente, posições de esquerda de grande lucidez. Foi um dos fundadores do Partido Socialista Brasileiro (1947). Jamais adotou o marxismo economicista, muito menos se deixou seduzir pelo discurso das esquerdas revolucionárias (autoritárias). Manteve-se fiel ao movimento chamado Esquerda Democrática, surgido no pós-45. Nesse sentido, cabe o epíteto de "democrata radical” que lhe apôs Candido, seu parceiro na fundação do PSB. Nos anos 1960, opôs-se ao golpe de 1964 e se aposentou da Universidade de São Paulo (USP), em 1969, em solidariedade a vários colegas cassados. Foi um dos fundadores do Partido dos Trabalhadores (PT), em 1980, então um partido que acendia as esperanças da esquerda brasileira - ou parte dela, na verdade, porque o trabalhismo renovado no PDT de Leonel Brizola era, então, uma vertente importante nesse campo político.

Raízes continuou à margem, nos anos 1970, mesmo após a edição de 1969, celebrada por Antonio Candido. Pouco adotado e discutido nos cursos de História, com a honrosa exceção da USP, onde lecionava desde 1956. Era frequente associar-se Raízes a Casa-grande e senzala, de Freyre, autor então amaldiçoado no meio acadêmico por ter apoiado o golpe de 1964, além de se aproximar do regime salazarista português. A suposta convergência entre os dois livros se fazia pela associação entre a tese do brasileiro como "homem cordial" - entendido como cordato, submisso, passivo -, e a tese freyriana de um passado colonial incruento, de um país formado à base da miscigenação racial e das contribuições recíprocas entre as culturas portuguesa, indígenas e africanas. De nada valeram as notas aclaratórias de Sérgio, expondo que o seu conceito de cordialidade procurava exprimir passionalismo, personalismo, irreverência em face de normas institucionais, nunca submissão. $\mathrm{O}$ autor se empenhou em esclarecer esse ponto desde 1948. A celebração da cordialidade foi colada em Raízes, assim como a da democracia racial o foi em Casa-grande, desde os anos 1960 e além deles. Duas distorções, que só começariam a ser revistas a partir dos anos 1980 .

Em todo caso, embora repelido pelos historiadores universitários, Casa-grande e senzala alcançou sua $16^{\mathrm{a}}$ edição em 1973, enquanto Formação do Brasil contemporâneo, valorizadíssimo no meio universitário, chegava à $13^{\mathrm{a}}$ edição. No mesmo ano, Raízes conheceu sua $7^{\mathrm{a}}$ edição. Se tais indicadores 
possuem algum valor, é possível dizer que a trajetória de Raízes continuava penosa, eclipsada pelos dois clássicos que lhe fizeram companhia na renovação historiográfica alavancada após a Revolução de 1930. Nos anos 1970, as ideias de Sérgio Buarque repercutiam menos do que as de um autor identificado à direita (Freyre), bem como as de um autor consagrado no campo da esquerda (Caio Prado).

Outro complicador da recepção de Raízes nos anos 1970 tem a ver com o crescente prestígio da chamada escola histórico-sociológica paulista, na mesma USP onde lecionava Sérgio Buarque -, o que nos conduz a observar a questão sob novo ângulo. O prestígio dessa escola contribuiu, antes de tudo, para a condenação, no Brasil (não no exterior), da obra freyriana - o que penso ter respingado em Raízes, por conta das associações que muitos faziam entre a interpretação de Freyre e a de Sérgio. Isso, em um momento no qual Raízes iniciava a sua arrancada em termos editorais.

O livro de Florestan Fernandes (amigo e interlocutor de Sérgio, na USP), A integração do negro na sociedade de classes (tese de cátedra, 1964), deu o tom dos novos tempos, ao denunciar a violência da escravidão e a completa despersonalização do africano escravizado desde o período colonial até a abolição - e mesmo depois, vítima de implacáveis preconceitos sociorraciais (Fernandes, 1978). Florestan é considerado o introdutor da "sociologia crítica" no Brasil, entendida como uma sociologia não apenas acadêmica, senão engajada na ação social, além de articular, no campo teórico, o pensamento marxista com o weberiano. A dedicação de Florestan ao estudo combativo dos preconceitos raciais no Brasil conduziu à formação de um núcleo de pesquisadores altamente qualificado, a exemplo de Fernando Henrique Cardoso e Octávio Ianni, para citar apenas dois. Inspirados no pensamento dessa escola sociológica, vários trabalhos acadêmicos foram produzidos sobre a escravidão, a abolição e os preconceitos raciais no Brasil, cujo ponto de partida era, invariavelmente, a rejeição a Casa-grande e senzala.

Sérgio Buarque nada tinha a ver com essa viragem nos estudos sobre a escravidão brasileira, tema que, por sinal, nunca foi objeto específico de sua obra. O próprio Raízes não destacou o escravismo como pilar de nossa formação histórica, quer na primeira edição, quer nas seguintes. Sérgio tratou da escravidão, é claro, mas de modo bem atenuado, se comparado aos livros de Freyre e Caio Prado Jr. Tampouco Sérgio alinhou-se às posições de Freyre na década de 1960, ao contrário. Era muito próximo de Florestan e de seus assistentes, e, volto a lembrar, foi após a cassação, por força do AI-5, de Florestan, Fernando Henrique e Ianni, em 1969, que Sérgio requereu sua própria 
aposentadoria, em solidariedade aos colegas. Nem por isso Raízes e, sobretudo, suas obras posteriores saíram do limbo em que estavam naqueles anos. Faço minhas, assim, para concluir este tópico, as palavras de Alcir Pécora: "se ele (Sérgio) nunca chegou a ser despachado para as mesmas fossas infernais em que ardia Gilberto Freyre, desqualificado como ideólogo do conservadorismo oligárquico, não será exagero afirmar que andou pelas redondezas” (In: Monteiro; Eugenio, 2008, p.23).

\section{TeOria da América Versus Males de Origem}

É o momento de comentar como surgiu e se concretizou o projeto de Raízes, nas primeiras décadas do século passado. Com exceção dos especialistas da obra buarquiana, poucos sabem que o projeto desse livro era inicialmente mais amplo. No final dos anos 1920, Sérgio Buarque cogitou escrever uma Teoria da América, ideia que, segundo ele mesmo, só se firmou na temporada alemã, entre 1929 e 1930:

do que não me livraria depressa era do projeto de Teoria da América, pois justamente durante a estada no estrangeiro naqueles meus Wanderjahre alemães, ela principiará a ganhar forma definida. O contato com terras, gentes, costumes, em tudo diferentes do que até então conhecia, pareceu favorável à revisão de ideias velhas e à busca de novos conhecimentos que me ajudassem a abandoná-las ou depurá-las. (Holanda, 1979, p.29)

Sérgio escreveu essas linhas no final da década de 1970, na "Apresentação" do livro Tentativas de Mitologia. Tal reflexão foi apenas uma, dentre várias que ele realizou sobre Raízes, nos últimos 15 anos de vida, seja em artigos, conferências ou entrevistas. Em entrevista publicada em 1982, ano da sua morte, Sérgio mencionou que, ao regressar da Alemanha, trouxe consigo um "caderno de anotações” de cerca de 400 páginas que pretendia transformar em livro, o qual se chamaria Teoria da América. Acrescenta que, desse manuscrito, só aproveitou dois capítulos que, sem grandes modificações, "deram origem a Raízes do Brasil” (Apud Sanches, 2013, p.153). Tal depoimento provoca indagações de difícil resposta, à falta de informações precisas. Antes de tudo, de quais "ideias velhas" queria se livrar, abandonando-as, depurando-as? É certo que, ao projetar um ensaio histórico de envergadura teórica, Sérgio jamais pretendeu observar os cânones que priorizavam os fatos institucionais e os personagens célebres - e o mesmo vale para Freyre e Caio Prado. Nada de 
exposição linear, que havia consagrado o Varnhagen da História Geral do Brasil, nos anos 1850, nem do gênero incerto - diria - dos Capítulos de História colonial (1907), de mestre Capistrano, obra que combinava insights inovadores com ensaios convencionais. Mas dizer isso é dizer o óbvio.

Mais complicado é saber se Sérgio entendia as "velhas ideias" como a tradição elitista do pensamento social brasileiro desde o século XIX, atualizada nas primeiras décadas do XX, em meio ao avanço da urbanização e começo da industrialização no país. Nesse contexto, cada vez mais influenciada pelo paradigma raciológico adotado pela etnologia e mesmo pela sociologia da época, a maioria dos intelectuais brasileiros ficava entre lastimar o legado rural e oligárquico de nossa formação histórica, incluindo a herança portuguesa, e deplorar a má progênie do povo brasileiro - a mestiçagem, em particular. Em diversos casos, tais ideias levaram à conclusão de que o liberalismo e a democracia de tipo ocidental, no Brasil, eram inviáveis, quando não indesejáveis. Vários autores poderiam ser arrolados para ilustrar essa conclusão, a exemplo de Oliveira Viana, na sociologia política, ou Paulo Prado, no ensaio histórico. Como Sérgio se situava em face desse campo sociológico e ideológico, é matéria que tem animado diversas pesquisas. Não seria exagero dizer que Sérgio e Freyre compartilhavam desse ânimo renovador, cada um a seu modo, no período em que Raízes e Casa-grande e senzala foram pensados, escritos e publicados. Nos dois autores, pulsava a ambição de formular novas teorias para compreender a originalidade brasileira em termos históricos, identitários e culturais. Os resultados, a meu ver, foram muito diferentes, superando de longe as semelhanças - não sendo o caso, aqui, de seguir por esse atalho.

De todo modo, antes de propor uma reflexão sobre as raízes histórico-sociológicas do Brasil, Sérgio desejou formular uma teoria da América. De qual teoria se tratava? Difícil responder, pois ele abandonou o projeto. Mas é caso de citar a hipótese, lançada por Evaldo Cabral de Mello em posfácio a uma das edições de Raízes: "não seria excessivo supor que se trataria (a teoria da América) de uma leitura weberiana de sociologia comparativa dos processos de colonização nas Américas portuguesa, espanhola e inglesa" (Apud Holanda, 1995, p.190).

Quanto ao weberianismo de Sérgio, não obstante alguns questionamentos recentes, parece-me um traço incontestável de seu pensamento sociológico. Ele mesmo afirmou, várias vezes, ter-se aproximado da obra de Max Weber a partir da temporada em Berlim. Citou-o, várias vezes, na primeira edição de Raízes e nas seguintes, apesar de certas atenuações a partir da edição de 1948. Quanto à sociologia comparativa entre diferentes colonizações como base de 
sua "teoria da América", conforme supôs Evaldo, Raízes oferece bons indícios ou mesmo eixos de argumentação: 1) o contraste explícito entre os estilos castelhano e português de colonizar, o primeiro construtivo, planejado, empenhado em implantar a hispanidade na América, urbanizador, interiorizador; o segundo feitorial, litorâneo, rural, improvisado, indiferente à transposição ou não de uma "portugalidade" em terra brasílica; 2) o contraste, ainda que mais acanhado que o primeiro, entre a colonização ibérica, de um lado (agora tomada no conjunto) e a colonização inglesa na Nova Inglaterra, do ponto de vista cultural: a ibérica caracterizada pela detração do trabalho (considerado como "defeito mecânico" que embarreirava, junto à impureza de sangue, expectativas de ascensão social), pelo apego a hierarquias de inspiração aristocrática, em resumo, aventureira e personalista; a inglesa, nas colônias do norte, puritana, socialmente disciplinada, agregativa, apegada à ideia do trabalho como virtude; 3) o contraste entre a colonização portuguesa e a colonização holandesa - esta muito celebrada por intelectuais da época, e neste caso Sérgio Buarque desmistifica a excelência da colonização flamenga, que para ele não passou de um projeto, inviabilizado, na prática, pela ausência quase total de comunicação entre colonizadores e colonizados, tudo agravado pelo perfil social dos primeiros, "recrutados entre aventureiros de toda espécie", entre franceses, ingleses, alemães, irlandeses, poloneses e até neerlandeses, é claro (Holanda, 1976, p.31-36).

Nada disso consta da primeira "teoria da América” produzida no Brasil. Refiro-me ao livro de Manoel Bomfim, A América Latina: os males de origem, publicado em 1905. Livro de repercussão péssima, quando veio à luz, alvo de resenhas destrutivas, a exemplo da de Silvio Romero. O próprio Manoel Bomfim abandonou, por décadas, seu ânimo ensaísta - ele que era médico de ofício e educador por vocação. Seja como for, Bomfim formulou uma teoria coerente sobre a história latino-americana, de algum modo inspirado no pensamento marxista, quando menos na convicção de que a história das sociedades é a história da exploração do homem pelo homem. Bomfim defendeu, com eloquência, a tese de que os males de origem das sociedades ibero-americanas decorriam do parasitismo econômico praticado pelas metrópoles colonizadoras, que sugaram a vitalidade do continente por dentro. Concebia as sociedades como "organismos sociais", relacionando-os com os "organismos biológicos".

O pensamento de Bomfim se aproximava da corrente filosófica conhecida como organicismo, que encara a sociedade e a cultura como organismo vivo, "uma totalidade singular e espontânea dotada de um princípio interno que orienta as apropriações segundo a sua natureza, isto é, seus quadros de vida" 
(Eugenio, 2011, p.297). Amadurecido no último quartel do século XIX, o paradigma organicista, aparentado (mas não idêntico) ao paradigma raciológico, refinou-se no início do século XX. O polêmico livro A decadência do Ocidente (1918-1919), de Oswald Spengler, oferece um modelo dessa filosofia, ao conceber as "criações culturais, quaisquer que sejam" como expressivas de uma "imagem do mundo que nasce e morre com cada cultura". Bomfim não seguiu Spengler, nem poderia, escrevendo em 1905, mas pensava a história em termos organicistas, talvez baseado em versões mais biologizantes - inspiradas no darwinismo social -, embora crítico acérrimo das conclusões racistas. Biologizou a interpretação da história latino-americana, identificando seus males de origem, suas doenças de formação. Enfrentou variada gama de autores, nacionais ou estrangeiros (sobretudo franceses), que deploravam a miséria que a miscigenação racial podia provocar nas civilizações. Ancorou-se em uma lógica racialista, enfim, para combater os preconceitos raciais, chegando ao ponto de invertê-los, ao celebrar a miscigenação como processo social e biologicamente saudável (Bomfim, 2000).

Se Bomfim não leu Spengler, Sérgio leu diversos organicistas. Estão incluídos, presumo, na "sociologia histórica dos alemães" que Antonio Candido identificou, genericamente, entre as matrizes teóricas de Raízes. Não quero dizer, com isso, que Raízes tenha se inspirado em Bomfim na concepção de sua "teoria da América", jamais publicada, salvo pelos dois capítulos dela aproveitados em 1936. Nem poderia dizê-lo, pois, não apesar das diferenças, as duas primeiras edições de Raízes celebravam a colonização portuguesa, como apontou João César de Castro Rocha (In: Monteiro; Eugenio, 2008, p.230ss). Bomfim, ao contrário, condenou o bacilo da colonização portuguesa desde sempre.

Mas a presente comparação não é ociosa, pois João Kennedy Eugenio demonstrou a força da filosofia organicista na primeira edição de Raízes. As similitudes de interpretação são muito posteriores, se tomarmos a quinta edição de Raízes como referência. Nela, sim, encontramos o pessimismo quanto à colonização ibérica, em especial a portuguesa, ao enraizamento de tradições impeditivas da modernização do país, todas de origem colonial, estendidas ao Brasil imperial. É verdade que algum pessimismo desse jaez pode ser visto na edição original, pois há ambiguidades variadas em Raízes. O fato é que a interpretação pessimista sobre a nossa história aparece na obra de vários intelectuais brasileiros, à esquerda ou à direita, democratas, autoritários e socialistas, na primeira metade do século XX.

O problema colocado neste tópico reside em que Raízes foi concebido como "teoria da América", o mesmo objeto de Bomfim. Ninguém menos do 
que Antonio Candido registrou essa lacuna, em texto escrito em 1998: “Sérgio Buarque de Holanda não lera Manoel Bomfim”. Apressa-se, porém, a sublinhar que a posição de Sérgio era diferente, embora reconheça que ambos não nutriam qualquer saudosismo em relação ao Brasil patriarcal nem sublinhavam a família como "estrutura de referência" analítica, mas buscavam, cada um a seu modo, "extrair do passado uma lição que evite posições conservadoras no presente" (Candido, 2008, p.85-86). Sigo, no essencial, o ajuizamento de Candido, salvo quanto à valorização do patriarcalismo, do familismo, como aspecto estruturante da história brasileira. Isso porque, em Manoel Bomfim, a discussão sobre o patriarcalismo é nula. Já em Raízes ela tem alguma ou muita importância. Fica sem resposta, portanto, a pergunta sobre o porquê de Sérgio não ter citado Bomfim em Raízes - uma vez que o livro do autor sergipano tratou dos "males de origem" do continente, 30 anos antes - além do que o livro de Sérgio pretendia ser uma "teoria da América". Eis um imbróglio que pode estimular, quem sabe, pesquisas futuras.

\section{RAÍZES AMBIVALENTES: O IMBRÓGLIO DAS EDIÇõeS}

Evaldo Cabral de Mello contribuiu para o aprimoramento dos estudos sobre Raízes do Brasil ou, pelo menos, estimulou muitas pesquisas. No citado posfácio de Raízes (1995), sublinhou a inflexão da estratégia intelectual de Sérgio entre a publicação de Raízes, em 1936, e sua produção posterior, datada dos anos 1940-1960.

Observar-se-á, então como o discurso de corte sociológico (no bom sentido) cedeu lugar à concreção do discurso historiográfico e como, em lugar da tentativa de identificar a gênese das mazelas da nossa formação social, surge a análise rigorosa dos tópicos claramente definidos nos seus contornos conceituais. (Apud Holanda, 1995, p.192)

Evaldo advertiu, porém, que tal inflexão somente poderia verificar-se a partir da primeira edição de Raízes, cotejada com a de 1948 ou, "alternativamente, passar diretamente da leitura do texto de 1936 à de Monções ou Caminhos e fronteiras".

A observação atilada de Evaldo pôs em xeque, com grande repercussão, a continuidade e a coerência do pensamento buarquiano. Diversas pesquisas avançaram, nos anos 1990, comparando as duas edições de Raízes, contrastando suportes teóricos, inventariando acréscimos ou subtrações de parágrafos e, 
sobretudo, mudanças conceituais. Houve ainda os que se dedicaram a cotejar o Sérgio dos anos 1920, crítico literário, com o ensaísta dos anos 1930 (Avelino Filho, 1987, p.33-41). Alguns compararam Raízes com livros posteriores de Sérgio (Wegner, 2000). Outros, enfim, confrontaram obras diferentes do autor, produzidas nos anos 1950 (Nicodemo, 2008). Limito-me, aqui, a comentar os principais contrastes que os autores recentes têm apontado, sublinhando, antes de tudo, uma característica comum aos novos estudos: excelente análise intra e intertextual, densidade teórica das reflexões, espírito crítico de preferência a comentários celebratórios.

Nessa linha de investigação, prestou-se mais atenção ao prefácio, que o próprio Sérgio incluiu à segunda edição de Raízes. Em não mais que uma página com três parágrafos, escrita em 1947, o autor informa que o livro foi "consideravelmente modificado" em relação à versão original. Publicá-lo, sem alterações, prosseguiu, "seria reeditar opiniões e pensamentos que, em muitos pontos" não mais o satisfaziam. Diz ter abandonado a ideia de proceder a "uma revisão verdadeiramente radical do texto", pois isso equivaleria a escrever um novo livro, mas reitera que não deixou de "alterá-lo abundantemente". Comenta por alto, enfim, a razão de não ter examinado, no último capítulo, "a circunstância da implantação, entre nós, de um regime de ditadura pessoal, de inspiração totalitária" (Estado Novo getulista); informa sobre a agregação de dois capítulos e sobre os critérios das notas complementares (Holanda, 1976, p.XXXII).

O que há de mais substantivo nesse texto é a profissão de fé democrática sugerida pela condenação da ditadura de Getúlio Vargas, instituída pouco depois da primeira edição de Raízes. Sobre as alterações de fundo, nem uma só palavra. Estas foram mesmo abundantes, a começar pelo acréscimo de 116 parágrafos (cerca de 1/3 da edição corrente), além de várias retificações, supressão das epígrafes, modificações vocabulares e conceituais, exclusão de autores e de algumas citações textuais (como uma de Alcântara Machado), cuidadosa atenuação ou eliminação de adjetivos outrora aplicados a diversos autores (Eugenio, 2011, p.372-394).

Um contraste, muito bem estudado por Robert Wegner, tem a ver com a mudança de juízos acerca do bandeirantismo paulista. No cotejo das edições de 1936 e 1948, a "grandiosa obra das bandeiras paulistas" virou "a obra das bandeiras paulistas"; "a expansão dos pioneers paulistas, entre os quais se destacam figuras fundamentais, como a desse extraordinário Antônio Raposo Tavares...", perdeu o aposto monumentalizador, embora tenha conservado o adjetivo para esse bandeirante. Isso se explica sem dificuldade. O Sérgio de 
1936 ainda era muito cativo da bandeirolatria paulista (chegou a dar um curso de "bandeirologia"), que se pode resumir no livro de Alfredo Ellis Jr.: Raça de gigantes (1924). O Sérgio de 1948 já havia publicado Monções, estava prestes a concluir "Índios e mamelucos", base do futuro Caminhos e fronteiras (1957). Em 1948 Sérgio havia completado a transição entre o ensaísta e o historiador, adaptando (ou invertendo), para o Brasil, o grande tema de Frederick Jackson Turner, The significance of the Frontier in American History (1893). Não caberia mais celebrar, senão analisar em perspectiva histórico-antropológica, a história das bandeiras paulistas. Foi o que ele fez nos anos 1940. Fica sem explicação, no entanto, o fato de ter excluído, da segunda edição, a citação de Alcântara Machado, o primeiro a desmistificar os paulistas em Vida e morte do bandeirante (1929). O mesmo vale para Viana Moog, autor gaúcho de Bandeirantes e pioneiros (1964), ignorado em Caminhos e fronteiras (1957). Alcântara Machado, porém, foi resgatado nesse livro. Citado uma vez, ainda bem.

Entre as várias modificações cometidas na segunda edição de Raízes, o autor mais cortado, entre os brasileiros, foi Gilberto Freyre: despojado de vários adjetivos, suprimidas várias referências a Casa-grande e senzala. Esse é assunto que nos interessa de perto, nem tanto pela assimilação desabonadora que, nos anos 1960, far-se-ia entre Gilberto e Sérgio, como mencionei, senão pela proximidade intelectual entre ambos nos anos 1930. Freyre, que então dirigia a coleção Documentos Brasileiros da editora José Olympio, foi o prefaciador da primeira edição de Raízes. Fossem tais alterações introduzidas na quinta edição (1969), considerada definitiva por Sérgio, quando Freyre já alinhava com a ditadura militar, teríamos razão política plausível para tal procedimento. Mas não foi esse o caso. Por que o "divórcio" intelectual de 1948 ?

O mínimo que se pode constatar é que os dois não seguiam a mesma trilha política em 1948, inclusive militavam em partidos opostos. O primeiro foi um dos fundadores do recente Partido Socialista Brasileiro (1947), enquanto o segundo o foi da União Democrática Nacional (UDN), partido pelo qual se elegera como constituinte (1946). Gilberto dava os primeiros passos na adesão ao salazarismo, Sérgio jamais o faria. Até que ponto o desencontro político entre os autores, sobretudo no pós-45, ajuda a compreender as supressões de Freyre efetuadas na segunda edição de Raízes, eis assunto que merece pesquisa.

A diferença mais substantiva entre as duas edições de Raízes nada tem a ver com as ideias de Freyre. Trata-se de uma reviravolta conceitual que se pode resumir em uma palavra: desgermanização - como o fez João César de Castro Rocha (In: Monteiro; Eugenio, 2008, p.256). Na segunda edição, conceitos como "visão de mundo" (Weltanshauung) e "formas de vida" ou "mundo da 
vida" (Lebenswelt) são substituídos, respectivamente, por "ideias" e "formas de convívio". João Kennedy Eugenio sugeriu que as alterações desgermanizadoras resolveram o essencial do desconforto de Sérgio com a primeira edição de Raízes, em especial a filosofia organicista de matriz alemã (Lebenphilosophie). A edição de 1948 teria adotado, segundo Eugenio, a perspectiva sociológico-progressista que marcou o enquadramento futuro do livro. Sociologia ainda alemã, vale dizer, pois inspirada em Max Weber, mas sem nenhuma vinculação com ideias depois apropriadas pelo nazismo.

O fato é que Sérgio não apenas depurou, o mais que pôde, o organicismo que pulsava na edição de 1936, como expurgou autores, a exemplo de Oswald Spengler, Carl Schmitt e Ludwig Klages. Em texto de 1979, 10 anos depois da quinta edição de Raízes, informou que o seu ritmo de leitura diminuiu deveras, no final dos anos 1920, a ponto de se desfazer de boa parte de sua biblioteca. Mas tal ritmo seria retomado no exílio voluntário em Berlim: "recomecei a ler - disse - mas recomecei mal, enfronhando-me em filosofias místicas e irracionalistas (Klages etc.) que iam pululando naqueles últimos anos da República de Weimar e já às vésperas da ascensão de Hitler" (Holanda, 1979, p.129-130).

Dois anos depois, em entrevista a Richard Graham, perguntado sobre a influência da historiografia alemã na concepção de Raízes, Sérgio rebateu: "isto é tudo uma justaposição conjectural e acidental. Eu vivi na Alemanha, mas isto não é suficiente para dizer que eu fui influenciado pelos historiadores alemães; eu também vivi na Itália, na França e nos Estados Unidos" (Apud Sanches, 2013, p.154). Réplica frágil, sobretudo porque as demais experiências internacionais lembradas são posteriores à publicação de Raízes, a exemplo da estadunidense, vivenciada em 1941, ou da italiana, datada dos anos 1950. Reveladora, porém, do mal-estar que o assombrava - e o assombrou até os últimos dias -, por ter sido tão germanófilo na juventude. A influência alemã era indiscutível, sobretudo na filosofia, bastando consultar as várias páginas que os comentadores da obra dedicaram às leituras de Wilhelm Dilthey, Georg Simmel e muitos outros, sem contar os contatos com Friedrich Meinecke.

A propósito, parece-me haver demasiada especulação sobre quais autores Sérgio leu ou não em sua temporada alemã. Alguns autores alemães só foram lidos ou aprofundados décadas depois do estágio berlinense. Incluiria nesse rol ninguém menos do que Leopold von Ranke (1795-1880) - considerado o "fundador" do historismo ou historicismo - que não aparece citado em nenhuma edição de Raízes. Ranke somente foi citado em Visão do Paraíso (1958). A partir de então, não há dúvidas de que Sérgio aprofundou ao máximo o seu conhecimento da obra de Ranke (Holanda, 1974), bastando citar o seu famoso 
artigo de 1974 - "O atual e o inatual na obra de Leopold von Ranke” -, ensaio magistral sobre teoria e metodologia da história. Mas não seria exagero dizer que a obra de Ranke não teve a menor importância para Sérgio, seja em 1936, seja em 1948 - sem falar nos demais estudos buarquianos dos anos 1940.

Quanto aos autores alemães expurgados na edição de 1948, eram os filiados à Lebenphilosophie - o tal organicismo. Na imensa maioria, eram filósofos ou sociólogos (difícil diferenciar as duas disciplinas na Alemanha desses anos). O desconforto de Sérgio com o Raízes de 1936 só pode ser compreendido em chave extratextual: o contexto do pós-guerra, passado já o Julgamento de $\mathrm{Nu}$ remberg, que condenou vários líderes nazistas à morte. Nazismo ou germanidade se tornaram quase sinônimos na segunda metade dos anos 1940. Diversos comentaristas recentes da obra buarquiana, como Sanches, afirmaram, com razão, que o contexto internacional, em 1948, não era favorável aos germanófilos, aludindo ao processo de "desnazificação" (Entnazifizierung) pelo qual passou o Ocidente em todas as esferas da vida, desde o campo intelectual, cultural, da imprensa e, obviamente, político (Sanches, 2013, p.154). Sérgio parece ter-se arrependido de sua germanofilia intelectual - de parte dela, na verdade - apesar de que a maioria dos intelectuais alemães admirados por Sérgio não tenha apoiado o nazismo, inclusive Ludwig Klages (Eugenio, 2011, p.191-193).

A desgermanização da segunda edição de Raízes, em termos filosóficos, é evidente, mas isso não significa dizer que a germanofilia intelectual do autor tenha desaparecido. Sérgio abandonou - repito - apenas parte do pensamento alemão ao qual se filiara nos anos 1930. O autor continuou "meio alemão" para usar expressão de Antonio Candido - ao longo de sua vasta obra, não só em Raízes. Em certo sentido, ele até mesmo aprofundou sua ligação com o pensamento alemão a partir da década de 1950. Basta constatar o papel estratégico que a obra de Ernst Curtius (1886-1956) ocupa na elaboração de Visão do Paraíso, escrita em 1958 e publicada no ano seguinte. Refiro-me ao livro de Curtius, publicado em 1948, Europäische Literatur und Leteinisches Mittelalter (traduzido para o português em 1957 como Literatura europeia e Idade Média Latina). Luiz Costa Lima resume o caso, em artigo de 2002: "foi o estudo da tópica por Curtius que serviu de principal ferramenta para que Sérgio Buarque pusesse em movimento e conseguisse um modo de articular sua imensa erudição, convertendo-a em um precioso instrumento interpretativo sobre a forma mentis dos colonizadores ibéricos" (Apud Monteiro; Eugenio, 2008, p.523).

Outra prova da persistente germanofilia de Sérgio Buarque em Visão do Paraíso nos é dada por artigo de Maria Silvia de Carvalho Franco, que destaca 
a importância de Albert Béguin, autor suíço e francófono. Silva Dias demonstra à farta os elos entre Visão do Paraíso e o livro inspirador de Albert Béguin, L'Âme romantique et le rêve: essai sur le romatisme allemande et la poésie français (In: Monteiro; Eugenio, 2008, p.536-539), publicado em 1937, reeditado em 1939 e 1946. Não sabemos qual foi a edição lida por Sérgio, porque ele não cita Béguin em Visão, à diferença de Curtius, ali citado duas vezes. Mas o importante, no caso, é o permanente interesse de Sérgio pela cultura e pela história alemãs, não sendo impossível que tenha lido outros livros de Béguin. Por exemplo, Faiblesse de l'Allemagne (1945), inscrito no debate sobre a culpabilidade alemã na guerra e as atitudes que a França deveria assumir diante da Alemanha derrotada (Tambarin, 2005, p.555-567).

Menos relevante me parece a discussão sobre a maior ou menor presença do pensamento weberiano na obra de Sérgio, inclusive porque o autor jamais suprimiu esse grande sociólogo alemão de qualquer edição de Raízes. Não obstante, para resumir, alguns comentadores afirmam que a presença de Weber diminuiu na segunda edição de Raízes, enquanto outros sugerem que aumentou. A polêmica por vezes resvala para a discussão sobre se o livro de 1936 era mais ou menos sociológico do que o de 1948 ou, por outra, se esta última edição confirma a transição do autor da Sociologia para a História. Pouparei o leitor das filigranas que tal debate enseja, mas não posso evitar comentário sobre o peso que alguns atribuem à maior ou menor presença do grande livro de Max Weber - A ética protestante e o espírito do capitalismo (edição alemã de 1925) - na reelaboração de Raízes. Robert Wegner e Pedro Meira Monteiro, autores já citados, convenceram-me de que Sérgio foi relativizando, ao longo das reedições de Raízes, a importância desse livro. Há uma extensa nota de Sérgio nesse sentido, inclusa na edição de 1948. No entanto, A ética protestante de Weber não me parece ser o livro crucial para averiguar o peso do weberianismo em Raízes. Irrelevante não é, porque Sérgio o valoriza quando relaciona a virtude atribuída ao trabalho manual pelos puritanos e o êxito da colonização na Nova Inglaterra. O essencial de Weber, porém, do que Sérgio não abriu mão, reside nos "tipos ideais" que o sociólogo alemão expôs em Economia e sociedade (edição alemã de 1934).

De sorte que averiguar se Sérgio foi mais ou menos sociológico, entre as edições de 1936 e 1948, talvez seja um falso problema, para o que vale lembrar o comentário de Evaldo Cabral de Mello no posfácio de 1995: "quem diz sociologia alemã da época (anos 1930-1940) diz também epistemologia histórica, pois desde Dilthey e Rickert, os problemas do conhecimento histórico encontravam-se no centro mesmo da reflexão sobre as ciências que hoje chamamos 
ciências humanas, mas que então ainda se designavam por ciências do espírito..." (Apud Holanda, 1995, p.189).

Seja como for, a relativa "desgermanização" de Raízes não resultou em qualquer tipo de "afrancesamento", apesar do crescente prestígio dos Annales no pós-1945. Aliás, a presença de autores franceses é quase nula, tanto na edição de 1936 como nas posteriores, incluindo o texto que Sérgio considerou definitivo (1969). Henri Hauser, por exemplo, só foi citado por Sérgio na segunda edição de Raízes: La Prépondérance Espagnole (1940). Mesmo assim, não passou de um comentário lateral sobre o centralismo castelhano em face dos demais reinos ibéricos, no tempo de Filipe IV. E não se trata de um exemplo de somenos. Sérgio fora assistente de Hauser nos anos 1930, quando este lecionou História Moderna na UDF. Hauser, grande iberista, foi o primeiro orientador de Fernand Braudel, a quem indicou para a missão francesa, enviada à USP nos anos 1930. Marc Bloch e Lucien Febvre, fundadores dos Annales, nunca foram citados em quaisquer edições de Raízes. Tampouco em Monções (1945) e Caminhos e fronteiras (1957). Sérgio apenas citou Febvre em seu livro de 1958, Visão do Paraíso, no caso, Le problème de l'incroyance au XVIe siècle (1942). Um livro cujo objeto é caro ao Visão: a força do espírito religioso e do pensamento mágico no século XVI europeu.

Isso quer dizer que Sérgio desdenhava da historiografia francesa? É razoável supor que sim, mas apenas nos anos 1930 e 1940. É também possível que tenha descoberto Marc Bloch após a publicação póstuma de Apologie pour l'histoire (1949), preparada por Febvre. Bloch iniciara o livro em 1941, mas o deixou incompleto e ingressou na Resistência Francesa (1943). Preso pela Gestapo, morreu fuzilado em 1944. Marc Bloch só se tornou mundialmente conhecido, como historiador, no período pós-guerra (Yamashita, 2015). Não é de surpreender que Sérgio tenha se aproximado da obra de Bloch somente no pós-guerra. O contato com esse livro de Bloch foi estimulante, desde então, para o autor, especialmente em suas reflexões teórico-metodológicas. Mas não é caso de exagerar essa aproximação, tratando-se de 1950. Em “Apologia da história”, breve artigo publicado na Folha da Manhã (1950), Sérgio Buarque sequer analisa o livro de Bloch. Inspira-se nele para dar título ao seu artigo; considera-o uma "pequena obra-prima que (Bloch) tinha em preparo às vésperas do seu fuzilamento pelos nazistas”. Cita La société féodale (1941), talvez de forma pioneira entre os historiadores brasileiros, qualificando-a como "admirável painel” do feudalismo europeu. Mas a "apologia” em causa é a que o próprio Sérgio faz do conhecimento histórico, em sentido geral: apologia de 
uma história que, embora dedicada ao passado, deveria sempre se ater ao presente, engajar-se nele.

O mesmo vale para outro breve artigo publicado no mesmo jornal, também em 1950, "Para uma Nova História” (Apud Costa, 2011, livro II, p.18-21). Sérgio não vai muito além de um combate aos historiadores seduzidos pelo "fato puro" - positivistas -, inspirado em artigo de Febvre de 1949, "Vers une autre histoire" (Apud Costa, 2011, livro II, p.22-29). Vale dizer que depois de citar Febvre, Sérgio não resiste à tentação de mencionar o filósofo e psiquiatra alemão Karl Jaspers, Vom Ursprung und Zeit der Geschicte (1949) ou “Da origem e do tempo na História". Germanófilo, portanto, mesmo ao valorizar historiadores franceses. Nesse artigo de Febvre só encontrei um dos famosos combates deflagrados nos Annales, desde 1929: aquele a favor de uma história-problema. O Sérgio desses dois artigos, ouso escrever, apenas flertava com a historiografia francesa. Convém colocar os pingos nos is. Sérgio continuava, não "meio", mas muito alemão, no modo de pensar a história.

$\mathrm{Na}$ faculdade de Filosofia da USP, aliás, o historiador pioneiro na divulgação da "nova história social francesa" foi, não Sérgio Buarque, senão Eduardo d'Oliveira França que, na sua tese de cátedra para História Moderna (1951), Portugal na época da Restauração, revela a influência decisiva de Febvre (França, 1997, p.414). É que França fora assistente de Fernand Braudel na Missão Francesa de 1937 e, desde então, passou a se familiarizar com o movimento dos Annales. Foi na cátedra de História Moderna da USP, não na de História da Civilização Brasileira, que a Nouvelle Histoire - a clássica - criou uma linhagem, uma tradição na historiografia brasileira.

Em todo caso, é certo que o flerte de Sérgio com os historiadores franceses, em 1950, evoluiu para uma expertise, sobretudo em termos teórico-metodológicos. Volto a citar o artigo sobre Leopold von Ranke (1974), no qual Sérgio sustenta as afinidades entre o historicismo alemão e a historiografia dos Annales, derrubando esquematismos já consagrados naqueles anos (persistentes, infelizmente). À guisa de ilustração, cito comentário de Sérgio sobre o quinto capítulo de Apologie, "Análise Histórica”, no qual Bloch compara o juiz e o sábio. "Julgar ou compreender?" - eis a questão colocada para o historiador em face de seu objeto. O juiz, fiel aos fatos comprováveis; o sábio (cientista), aberto às experiências, à pesquisa. "Os dois caminhos assinalados por Bloch não diferem substancialmente dos caminhos descritos e separados por Leopold von Ranke: o da filosofia que, no seu entender, é o reino das leis genéricas ou abstratas, e o da História, que, partindo da observação do único, em sua unicidade, deverá entretanto explicá-lo...” (Holanda, 1974, p.442-443). 
A acuidade de Sérgio Buarque é genial e, outra vez, remou "contra a maré”, que opunha o historicismo positivista a uma história explicativa de cariz marxista. Marc Bloch também era "meio alemão", língua que dominava: um intelectual apegado à história e à cultura alemãs. Patriota francês desde sempre, é verdade; judeu, sem o sê-lo, na prática; mas se não era germanista, muito menos germanófilo, estava convencido de que a Alemanha devia ser mais bem conhecida pelos franceses. Foi crítico frontal da humilhação imposta pela França ao país vizinho (inimigo hereditário) pelo Tratado de Versalhes (1919), terminada a Primeira Guerra Mundial (Bloch, 2011, p.32-116). Apologie não é livro que destoa, no essencial, dos preceitos da escola metódica alemã (rankeana), que Marc Bloch segue, temperando-a com a sua experiência de pesquisa e de vida, mormente no front das duas guerras (Schöttler, 1995).

No mesmo texto, aliás, Sérgio mergulha na obra de Fernand Braudel. Conhecedor do Mediterrâneo (1949), bem como do artigo "A longa duração" (1958), endossa a temporalidade histórica braudeliana: história em três níveis (temporais), que distingue: a primeira, "quase imóvel", visa ao homem nas relações com seu meio; a segunda, que já comporta maior grau de mobilidade, é uma "história lentamente ritmada: trata dos grupos e agrupamentos sociais, permitindo, por exemplo, estudar as economias e os Estados, as sociedades, as civilizações, até mostrar como essas vagas profundas podem operar no domínio da guerra, que não depende só das vontades individuais. E há por fim a história tradicional, das oscilações breves, rápidas, nervosas, dimensionadas pelo indivíduo, não pelo homem: agitação de superfície, vagas que a maré eleva em seu movimento possante: a história eventual (événementielle)..." (Holanda, 1974, p.476). Tais considerações, porém, dizem respeito ao historiador consolidado, já nos últimos 10 anos de vida, concluída a sua grande obra autoral publicada entre meados da década de 1950 e a de 1960. No autor de Raízes 1936 ou 1948 - nada há de historiografia francesa.

Em suma, o melhor da exegese que os especialistas têm feito sobre a obra buarquiana é a que aponta as transições do autor entre os anos 1920 e os anos 1960. Do crítico literário modernista, além de jornalista, ao ensaísta ou sociólogo de 1936 ou 1948. Do sociólogo ambivalente, da segunda edição de Raízes, ao historiador consolidado dos anos 1950-1970, opção abraçada por Sérgio Buarque desde os anos 1940 - malgré as indecisões de Raízes. Se a transição de Sérgio Buarque do ensaísmo sociológico à pesquisa histórica é sustentável, Raízes não serve como parâmetro de reflexão ou como base documental. 
SÉrgio BuARQUe E A POLÍticA

Raízes do Brasil foi livro publicado às vésperas do golpe que levou ao Estado Novo, comandado por Getúlio Vargas (1937). A segunda edição do livro apareceu em 1948, no pós-guerra, em cenário mundial consternado pelos massacres perpetrados pelos alemães - considerados nazis por vocação, fossem ou não. Ecos dos Julgamentos de Nuremberg (1945-1946), que condenaram à forca vários cardeais nazistas. Tempo inaugural da Guerra Fria, não nos esqueçamos dela.

A quinta edição de Raízes data de 1969, meses depois do AI-5, no Brasil, embora já estivesse preparada desde 1967. Nesse mesmo ano, Sérgio aceitou, constrangido, um convite da Escola Superior de Guerra (ESG) para proferir conferência sobre "Elementos básicos da nacionalidade: o homem" - temática única de uma série de palestras que a instituição vinha organizando desde 1966. Sérgio desconfiou de que fora convidado pela tese do brasileiro como homem cordial - estereotipada - e, provavelmente, por isso aceitou. Aproveitou o ensejo para externar que Raízes, desde 1936, condenava ditaduras. Mas qual terá sido, na USP, a repercussão do aceite em proferir conferência na ESG em 1967?

Em 1969, Sérgio publicou a segunda edição de Visão do Paraíso, definida como "biografia de uma ideia", no prefácio. Isso em anos de prestígio da história econômica e do paradigma marxista: modelo de conhecimento histórico e de praxis revolucionária simultaneamente, não só na USP, como no meio universitário. Poderia multiplicar evidências a respeito dessas coincidências. Convenhamos, nosso autor passou por variados tormentos em conjunturas políticas dramáticas, nacionais e internacionais, entre os anos 1930 e 1970. Digo isso para voltar às críticas lançadas contra Raízes, do ponto de vista político, com destaque para a de Leopoldo Waizbort (Waizbort, 2012). Alvo delas: o prefácio que Antonio Candido escreveu, em 1967. Wanderley Guilherme dos Santos, em entrevista de 1994, afirmou que Antonio Candido "inventou" Raízes, em comentário en passant, aludindo à monumentalização da obra na historiografia nacional (Santos, 1994, p.40-43). Foi seguido por vários pesquisadores, em especial quanto à opinião de que Sérgio, desde 1936, sempre foi um democrata radical, por esposar as causas populares na história do Brasil.

Exagero de Antonio Candido? Talvez, mas nem tanto nesse prefácio, senão em textos posteriores já citados. No prefácio de 1967, data venia, Candido celebra não apenas o Sérgio Buarque de Raízes, mas também o Gilberto Freyre de Casa-grande e senzala e o Caio Prado de Formação do Brasil 
Contemporâneo. Aos três autores, atribui "o sopro de radicalismo intelectual e análise social que eclodiu após a Revolução de 1930...”. Casa-grande foi realçado pela sua "força revolucionária" e pelo "impacto libertador", ancorado em larga informação, concebido com talento, uma "ponte", para não dizer superação, do que Sílvio Romero, Euclides da Cunha ou Oliveira Viana escreviam sobre o povo brasileiro - destratando-o, porque mestiço. Opinião corajosa, em 1967. Ou não? Formação, de Caio Prado, foi celebrado pela pesquisa minuciosa das crônicas sobre o Brasil Colonial e como "interpretação do passado em função das realidades básicas da produção, da distribuição e do consumo" (In: Holanda, 1976, p.XXI). História econômica inspirada no "materialismo histórico".

O texto de Antonio Candido não "inventou" Raízes como monumento da historiografia brasileira. Pode ter exagerado na dose, ao destacar a "nova história social dos franceses" como um dos suportes teóricos do livro. Mas, quanto à política, o exagero é discutível, ao menos no prefácio.

Na conferência proferida na ESG, em 1967, Sérgio afirmou que, em Raí$z e s$, em nenhum momento deixara "transparecer em suas páginas qualquer sedução pelos regimes de força. Publicado em 1936, quando andava em maré alta a pregação do Integralismo, oferecia ele, ao contrário, uma denúncia inequívoca do fascismo..." (Apud Monteiro; Eugenio, 2008, p.619). Vale citar, para concluir e, ao mesmo tempo, complicar a reflexão, um trecho da primeira edição de Raízes, no capítulo "Nossa revolução" (p.159), o mesmo capítulo que Antonio Candido elegeu como prova do radicalismo democrático de Sérgio Buarque:

Não seria difícil provar o que poderia ser o quadro de um Brasil fascista. Desde já podemos sentir que não existe mais nada de agressivo no incipiente mussolinismo indígena. Na doutrinação dos nossos "integralistas", com pouca corrupção, a mesma aparece nos manuais italianos, faz falta aquela truculência desabrida e exasperada, quase apocalíptica, que tanto colorido emprestou aos seus modelos da Itália e da Alemanha. (Holanda, 1976, p.141)

Como interpretar esse trecho, escrito em 1936, e mantido em todas as edições de Raízes? Possibilidades várias. Sérgio desprezava o Integralismo? Movimento então fortíssimo no Brasil, uma vez destroçada a ANL e reprimido o levante, em 1935, dos tenentes esquerdistas comandados por Prestes. Subestimava o "mussolinismo indígena" por considerá-lo "amolengado" (como disse Freyre da sociedade escravista no Brasil colonial)? Fazia pouco caso dos regimes 
fascista e nazista na Europa, não obstante a truculência, "quase apocalíptica", que neles viu? Não percebia o que se avizinhava no país, nem a escalada dos totalitarismos europeus? Truculentos, porém, coloridos? Não faço ideia.

Indagação final: a "Nossa Revolução", capítulo final de Raízes, acaso se referia à Revolução de 1930 e não a um longo processo inaugurado nos anos 1880, com a Abolição da escravidão no Brasil? Esta última tese é a do Sérgio em 1936 ou a de Caio Prado Júnior, em A Revolução Brasileira, publicado em 1966? Se foi no capítulo final de Raízes que Sérgio Buarque deu o primeiro passo como crítico das ditaduras, eis um assunto polêmico. O trecho citado é desconcertante. Pode embasar, quem sabe, a imagem do democrata radical, como sugeriu Antonio Candido, em 1967. Mas pode indicar, não o contrário (algum tipo de entusiasmo), senão uma certa indiferença. Discreta.

\section{REFERÊNCIAS}

AVELINO FILHO, George. As raízes de Raízes do Brasil. Novos Estudos CEBRAP, n.18, p.33-41, 1987.

BLOCH, Marc. Apologia da História. Rio de Janeiro: Zahar, 2002. A estranha derrota. Rio de Janeiro: Zahar, 2011.

BOMFIM, Manoel. A América Latina: males de origem. In: SANTIAGO, Silviano (Org.) Intérpretes do Brasil. Rio de Janeiro: Nova Aguilar, 2000.

CANDIDO, Antonio. A visão política de Sérgio Buarque de Holanda. In:

(Org.) Sérgio Buarque de Holanda e o Brasil. São Paulo: Ed. Fundação Perseu Abramo, 1998. p.81-88.

COSTA, Marcus (Org.) Sérgio Buarque de Holanda: escritos coligidos. São Paulo: Ed. Fundação Perseu Abramo; Ed. Unesp, 2011. 2v.

FERNANDES, Florestan. A integração do negro na sociedade de classes. São Paulo: Ática, 1978.

EUGENIO, João Kennedy. Um ritmo espontâneo: organicismo em Raízes do Brasil de Sérgio Buarque de Holanda. Teresina: Ed. UFPI, 2011.

FRANÇA, Eduardo d'O. Portugal na época da Restauração. São Paulo: Hucitec, 1997. GOMES, Ângela de C. História e historiadores: a política cultural do Estado Novo. Rio de Janeiro: Ed. FGV, 1996.

HOLANDA, Sérgio Buarque de. Visão do Paraíso. São Paulo: Cia. Ed. Nacional, 1968. . O atual e o inatual na obra de Leopold von Ranke. Revista de História, São Paulo, v.50, n.100, p.431-482, 1974. . Raizes do Brasil. 9.ed. Rio de Janeiro: J. Olympio Ed., 1976. . Tentativas de mitologias. São Paulo: Perspectiva, 1979. 
HOLANDA, Sérgio Buarque de. Raízes do Brasil. São Paulo: Companhia das Letras, 1995.

Caminhos e fronteiras. 3.ed. São Paulo: Companhia das Letras, 2008.

MONTEIRO, Pedro M.; EUGENIO, João K. (Org.) Sérgio Buarque de Holanda: perspectivas. Rio de Janeiro: Ed. FGV, 2008.

NICODEMO, Thiago L. A urdidura do vivido: Visão do Paraíso e a obra de Sérgio Buarque de Holanda nos anos 1950. São Paulo: Edusp, 2008.

SANCHES, Dalton. Entre formas hesitantes e bastardas: ensaísmo, modernismo e escrita da história em Raízes do Brasil de Sérgio Buarque de Holanda (1900-1956). Dissertação (Mestrado) - Universidade de Campinas (Unicamp). Campinas, 2013. SANTOS, Wanderley G. dos. Uma cabeça que bate contra a maré. Veja, São Paulo, 18 maio 1994, p.403.

SCHÖTTLER, Peter. Marc Bloch et Lucien Febvre face à 1'Allemagne nazie. Geneses, 1995, n.21, p.75-95.

TAMBARIN, Marcel. "Que faire de l'Allemagne - les germanistes français face à l'Allemagne après la guerre de 1939". In: CONGRĖS DE L'ASSOCIATION DES GERMANISTES DE L'ENSEIGNEMENT SUPÉRIEUR, 36. Frontières, transferts, échanges transfrontaliers et interculturels, 2005, Bern, Berlin, Bruxelles, Frankfurt am Main, New York, Oxford, Wien. Actes... p.555-567.

WAIZBORT, Leopoldo. O mal-entendido da democracia. Sérgio Buarque de Holanda, Raizes do Brasil, 1936. Revista Brasileira de Ciências Sociais, v.26, n.76, p.39-62, 2012.

WEGNER, Robert. A conquista do oeste: a fronteira na obra de Sérgio Buarque de Holanda. Belo Horizonte: Ed. UFMG, 2000.

YAMASHITA, Jouge G. As guerras de Marc Bloch: nacionalismo, memória e construção da subjetividade. Tese (Doutorado em História) - Universidade Federal fluminense. Niterói, 2015.

\section{NOTAS}

${ }^{1}$ Sou grato a Angela de Castro Gomes pela confiança e, sobretudo, pelos esclarecimentos sobre Sérgio Buarque nos anos 1930. Sou grato a João Kennedy Eugenio que, com sua expertise, discutiu variados pontos deste artigo, invertendo papéis: de ex-orientando passou a orientador. Sou grato a Denise Rollemberg, pela luz acerca da Europa que atormentou Sérgio Buarque nos anos 1930-40.

${ }^{2}$ Doutor em História Social pela Universidade de São Paulo (USP), Professor Titular (História Moderna) aposentado da Universidade Federal Fluminense (UFF), Pesquisador I-A do CNPq, Cientista do Estado (Faperj) e Professor Visitante da FFP-Uerj.

Artigo recebido em 4 de julho de 2016. Aprovado em 26 de agosto de 2016. 